過電圧を高め, 電極に多量の水素の発生するのをおさえ るためと, 析出したコバルトのアマルガム化によるコバ ルトの電極への保持を目的としたものである.この場合 㤦用した水銀電極の水銀メッキの厚さは，水銀が均一に 電極に析出しているものと仮定すると，水銀の密度，析 出量, モル数, アボガドロー数, 電極の表面積などに関 係し，てれらの值を用いて算出するとほぼ半径方向の水 銀層の厚みは $10^{4}$ 個程度のものであると考えられる.

この際, コバルトの電解析出量 $(W)$ および還元に要 几た電気量 $(Q)$ は次式によって求めたものである.

$$
\begin{aligned}
& Q=\frac{n \boldsymbol{F} x}{2.22 \times 10^{12} \times K \times S \times W_{, n}} \\
& W=1.39 \times 10^{-10} \times(\mathrm{dps}) \quad \cdots \cdots
\end{aligned}
$$

また, 電気量と析出量との関係はフォラデーの法則よ り次式で与えられる。

$$
W=\frac{W_{m} \times Q}{96484 \times n}=3.05 \times 10^{-4} \times Q
$$

ただし， $W_{m}$ : コバルトの原子量, $K$ : 計数効率 $(6.79$ $\%), S$ : 比放射能 $(\mathrm{c} / \mathrm{g}), x$ : 計数率 $(\mathrm{cpm})$ である.

さらにまた本法は共存する $\gamma$ 線放射体の $\gamma$ 線エネルギ 一に測定器の分解能以上の差がある場合， $\gamma$ 線スペクト ロメトリ一を使用し，分別定量が可能であり，目下検討 蚛である。

（昭和 36 年 11 月，ポーラログラフ討論会にて発表）

\section{交献}

1) 舘 勇, 神原富民, 塚本 務: 電化, 18, 356, 386 (1950).

2) S. Brukenstein, T. Nagai : Anal. Chem., 33, 1201 (1961).

3) J. W. Ross, R. D. Demars, I. Shain : ibid., 28, 1768 (1956).

4) I. M. Kolthoff, J. J. Lingane : "Polarography”, Vol. I, p. 33 (1952), (Interscience Publishers, New York).

$$
\text { sis }
$$

Micro-coulometry of cobalt using cobalt60. (Radiometric Polarography. II.) Mutsuaki Shinagawa, Hiroyuki Nezu and Tadaharu TamaI (Department of Nuclear Engineering, College of Engineering, Osaka University, Miyakozima-ku, Osaka)

A coulometry through the measurement of radioactivity of deposits was examined with several kinds of microelectrodes. The solution $(50 \mathrm{ml})$ containing $5 \times 10^{-3} \mathrm{~F} \quad \mathrm{Hg}\left(\mathrm{NO}_{3}\right)_{2}-0.1 \mathrm{~F} \quad \mathrm{HNO}_{3}$ and $103 \mu \mathrm{c}{ }^{60} \mathrm{Co}$ was the best among the solutions examined. The electrolysis was performed at the controlled potential of $-1.50 \mathrm{~V}$ versus S. C. E. To determine the amounts of cobalt electroreduced to metallic state, $\gamma$-rays from cobalt- 60 were utilized and were measured with a scintillation counter.

From the experimental results, it was found that the weight of cobalt deposited or the quantity of the electricity passing through the electrode could be determined with a sensitivity of $2.87 \times$ $10^{-8} \mathrm{~g}$ Co or $0.94 \times 10^{-4}$ coulombs.

(Received Jan. 5, 1963)

\title{
定電流電量分析法による二酸化ウラン中のウラン(VI) の定量
}

\author{
武内 次夫*, 吉森 孝良**, 加藤 喬 $* * *$
}

\begin{abstract}
核然料用の二酸化ウラン中のウラン $(\mathrm{VI})$ を，硫酸チタンを電解液に使用する定電流電量分析法によ って定量した. まず試料の溶解方法について検討し, 硫酸（約 $2 N$ ) 数 $\mathrm{m} l$ と $1 \sim 2$ 滴のフッ化水素酸 との混合溶液を用いれば, 従来使用されている熱濃りン酸よりも, いっそう容易に溶解するてとができ た。 またてれによって，電解液中でリン酸チタンが讴殿するような困難もなくなった。つぎにウラン （VI）定量のときの定量限界を低くするために，定電流電量分析の終点決定に，高感度電流終点法を用 いた. 乙の場合, 指示回路電位差は $0.14 \sim 0.16 \mathrm{~V}$ (vs. S. C. E.) でよい結果が得られるととがわかった. 以上の方法によって 13〜1240 $\mu \mathrm{g}$ のウラン $(\mathrm{VI})$ を定量し，また，実際の二酸化ウラン扔よで八三酸 化ウランの組成分析を行ない, いずれも満足すべき結果を得た。 ての定量下限から考孚て, 従来の方法 よりもいっそうよい感度で, より迅速にO/Uの此が求められることがわかった。
\end{abstract}

* 名古屋大学工学部工業分析化学教室 : 名古屋市千種区不老町

** 岐皁大学工学部工業化学科 : 岐阜県各務原市那加町

*** 笠松中学校 : 岐阜県羽島郡笠松町 


\section{1 緒言}

最近，が国においても核燃料として金属ウランのほ かに二酸化ウランの使用が検討されている.この酸化ウ ラン中の不純物の定量は，これまで金属ウラン中の不純 物の定量法として行なわれてきた方法が利用できると考 号れる.しかし二酸化ウランは空気中に打いて, 徐々 に酸化される傾向があり，これを核然料として使用する とき，試料中の酸素とウランとの比（すなわち $\mathrm{O} / \mathrm{U} の$ 值）を知ることがきわめて重要である。

従来はこの分析方法として，空気中で高温に加熱し， 八三酸化ウランにしたときの重量增加を測定して酸素を 定量する乾式方法1や，濃りン酸を用いてウランの酸化 をさけながら試料を分解して水溶液したのち， ウラン (IV) と共存するウラン (VI) を定量する方法などが報告 されている，このウラン (VI) の定量には, 直流および 交流のポーラログラフ法2 ${ }^{2}$ (6), 第一チタン塩標潐溶液に よる電位差滴定法7)8)， あるい注定電位電量分析法9 (12), などの方法が利用されている。しかしこれらの方法にお いては，定量下限が高かったり，正確度がじゅうぶえで なかったり，また分析にかなり長時間を要するなど，ま だ不満な点がある.ことに従来は試料の分解に高濃度の リン酸が使用されているが, この場合は反応容器がおか されるため問題をおこしやすい，またその後の処理にお いて，このリン酸の存在が好ましくない影響を与える場 合がある.

著者らは定電流電量分析法によって，金属ウランを はじめ各種材料中の微量成分を定量して好結果を得た が，本報においてはこの方法を二酸化ウラン中のウラン （VI）の定量に応用した．すなわち，多量のウラン(IV) と共存するウラン $(\mathrm{VI})$ を定量する場合には，定電流電 量分析法によってウラン(VI) をウラン (IV) にして定量 するのが合理的である.ウラン (VI) の定電流電量分析 法としては, チタンの電解液を使用する方法が報告され ている13)14)。しかし，この報告はかなり多量のウランの 定量について検討されたもので, 微量のウラン (VI) の 定量は検討されていない。また二酸化ウラン試料の分解 に,これまでのようにリン酸を使用すると,上記文献13)14) のチタン電解液を使用した場合, チタンがリン酸塩とし て沈殿してくるので, 定量は不可能であった. したがっ て,チタン電解液が使用できるような試料分解法を研究 し，新しく硫酸と少量のフッ化水素酸とを使用する方法 を考案し，きわめて容易に，かつ迅速侙料を分解するこ とができた．またウラン(VI) の定量においても，13 $\mu \mathrm{g}$ までの微量のウランを定量できることがわかった。
2 装置, 試薬および実験方法

\section{$2 \cdot 1$ 装}

装置はFig. 1 亿示したと扣りで,てれまでに報告した もの15)とほとんど同じである。電極は指示極が $1.5 \mathrm{~cm}$ 角，発生極は $1 \times 2 \mathrm{~cm}$ 角のそれぞれ白金板を打もに使 用し，一部の実験では指示極に $1 \mathrm{~cm}$ 角の白金一イリジウ 么 $(10 \%$ Ir $)$ 板を使用した。 また，発生対極は径 0.1 $\mathrm{mm}$, 長さ $2 \mathrm{~cm}$ の白金線を使用した。霜解えうは容量 約 $70 \mathrm{ml}$ の高型口なしビーカーを用い, 検流計の感度は $1.0 \times 10^{-8} \mathrm{~A}$ であった. 定電圧装置は出力電瓜約 $250 \mathrm{~V}$, 電流容量約 $50 \mathrm{~mA}$ のものを使用した。また時間の測定 はストップウオッチにより，溶液のかきまぜは，電極が 露出しない程度でなるべく速くかきまぜるようにした。

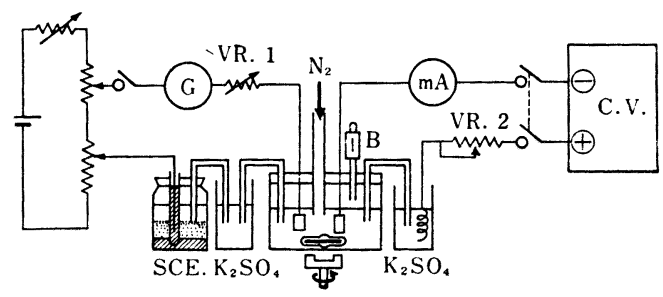

Fig. 1 Apparatus

VR. $1: 1 \mathrm{M} \Omega$ Variable resistor VR. $2: 50 \mathrm{k} \sim 1 \mathrm{M} \Omega$ Variable resistor

B : Bunsen valve

C. V. : Constant voltage supply $250 \mathrm{~V}, 50 \mathrm{~mA}$

\section{$2 \cdot 2$ 試 薬}

試薬はすべて特級品を使用したが，とくにその精製は 行なわなかった：三，三の溶液の作製方法を述べる。

硫酸チタン溶液：市販四塩化チタン約 $29 \mathrm{~g}$ を Malmstadt ら ${ }^{16)}$ の用いた装置によって塩酸に溶解する。乙 れに硫酸約 $125 \mathrm{ml}$ を加え，ビーカーに移してしずかに 加熱し，わずかに沈殿が生成しはじめる程度まで硫酸白 煙を発生させたのち冷却して, 水で約 $250 \mathrm{ml}$ 亿うすめ た.

ウラン (VI) 標準溶液 : NBL 製三酸化ウラン (U : $82.1 \%$ ）の一定量をはかりとり，硫酸およご少量の過酸 化水素水で分解後, 過剩の過酸化水素を煮沸分解して冷 却する。乙れをメスフラスコを用いて一定量にうすめた ものを保存用標準溶液とする。使用にさいしては，この 一定量を酸素を除いたうすい硫酸で一定容積にうすめ た.

その他の試薬類については略するが，硫酸中の不純物 そついて十分に注意すべきことは，前報15)に示したと同 様である．また，窒素ガスはアルカリ性ピロガロールな ぞで完全に酸素を除いてから使用する必要がある。

\section{$2 \cdot 3$ 実験方法}

ウラン (VI) の定電流電量分析法としては，これまで の研究をもとにして，つぎの指針をたてた。 


\section{〔指針 1〕}

（a）電解液の調製 硫酸チタン溶液 $20 \mathrm{ml}$ を Fig. 1 の電解そうにとり, 硫酸第一鉄溶液 $(1 \mathrm{mg} \mathrm{Fe} / \mathrm{ml}$, 硫酸約 $5 M$ ) 約 $10 \mathrm{~m} l$ を加える.これにウラン (IV) 溶 液 (二酸化ウラン約 $0.1 \mathrm{~g}$ を, 後述の方法で溶解し, 硫 酸ウラン (IV) の沈殿が生成する直前をで濃縮したも の.これは実際の場合は，前の実験の残りの試料溶液を 濃縮して使用できる）を加え，必要ならば硫酸を加えて， 総容積 $35 \sim 40 \mathrm{ml}$, 硫酸濃度 $6 \sim 8 M$ に調節する. これ にさらにフッ化水素酸 3〜 5 滴を加えて電解液とする.

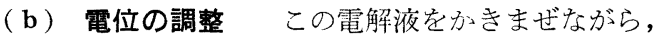
完全に酸素を除いた窒素ガスを毎分約 $300 \mathrm{ml}$ の速さで 約 20 分間通して電解液中の酸素を除く.つぎに窒素ガ スの流速を每分 $50 \sim 100 \mathrm{ml}$ とし，発生回路に電流を通 して電解還元を行ない, 溶液の電位を $0.14 \sim 0.16 \mathrm{~V}(\mathrm{vs}$. S. C.E.) に調節すると同時に, 発生回路の可変抵抗器を 加減してその電流を適当な值にする.ただしこの場合, 電解液の電位洼発生回路の電流を切ってから測定するよ うにする。

（c） 電量分析 以上のようにして電位を調整した 電解液に, ウラン (VI) を含む試料溶液をピペットの先 をブンゼンバルブのすき間からさし込えで加えると，電 解液の電位が変化して指示回路の検流計が振れる.この 振れがもとにもどるまで定電流で電解還元を行ない，こ のときの電解時間をストップウオッチで測定し, 電解電 流と電解時間とからフォラデーの法則によってウラン （VI）量を計算する.この場合電解電流を通しているう ちは，検流計の指示は多少変動することが多い，したが って，終点に近づいてきたら電解を中止し（もちろんス トップウオッチも止める)，30 秒ないし 1 分間放置して 検流計の静止するのを待ってから読みとり，さらに短時 間の電解责行なう操作をくり返して, 電解電流を切って から 30 秒ないし 1 分間後に検流計の振れがもとにもど った点芯終点上方る。

以上の実験寺法において，とくに注意しなけ礼ばなら ないの注，電解液の電位を安定させることである。すな わ号，（ｂ）操作で電解液の電位をある值にしてから， 試料溶液を加えないで拈いた場合，少なくとも電解が終 了する程度までの時間内に，電解液の電位が変化しては ならないわ忖である。したがって, 電解液には常に窒素 ガスを通しておき, 試料溶液を加えるときにもブンゼン バルブのすき間からピペットの先をさし込えで加えるよ うにする必要がある。このほかに硫酸中に不純物が含ま れている場合法もちろん，電解液中に塩素イオンがはい った場合などにも, 電解液の電位が不安定になりやすい
ので注意しなければならない。この点窒素ガスの精製に は, 塩化第一クロムを使用するよりも, 硫酸第一チタン やピロガロールなどを使用したほうが安全である。

以上のような点に十分注意すれば電解液の電位は安定 になるが,いくぶえ不安定な場合でも，このような原因に よる電解液の電位の上昇は, 一般に比較的短時間内では ほぼ一定の速度とみなせる場合が多いから，それを補正 することにより,かなり正確な結果を得ることもできる。

\section{3 実 験 結果}

\section{$3 \cdot 1$ 終点電位の決定}

従来, チタンの電解液を用いてウラン (VI) を定電流 電量分析法で定量した報告では, 終点は電位差測定法ま たは電流測定法によって決定している。しかし，この方 法をさらに微量のウラン (VI) の定量に利用するために は，これらの終点決定法を用いては定量は困難であり， 高感度電流終点法 (sensitive amperometric end point procedure) を採用する必要があった。

この終点決定法において重要な点は, 指示回路電位差 計の電位すなわち試料を加える前と終点とにおける電解 液の電位である.この電位の最適值を求めるために,

Fig. 2 に示した約 $1 \mathrm{mg}$ のウランについての電位差滴 定曲線の, 終点付近における種々の電位 $(0.18 \sim 0.10 \mathrm{~V}$ vs. S. C. E.) において, 指針 1 によってウランを定量 した結果を Table I に示した。

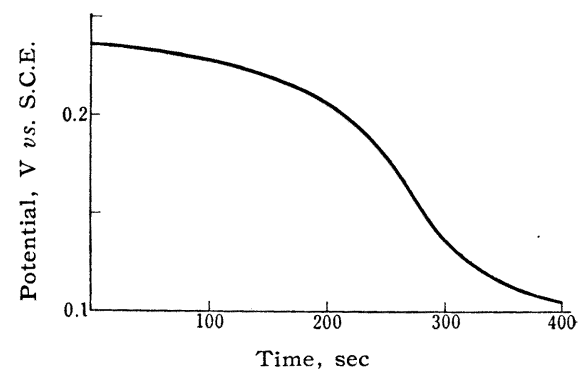

Fig. 2 Potentiometric titration curve

Table I Effect of the indicator circuit potentials on uranium determination

\begin{tabular}{cccc}
\hline $\begin{array}{c}\text { Indicator circuit } \\
\text { potential } \\
\text { (Vs. S. C. E.) }\end{array}$ & $\begin{array}{c}\text { Uranium } \\
\text { taken } \\
(\mathrm{mg})\end{array}$ & $\begin{array}{c}\text { Uranium } \\
\text { found } \\
(\mathrm{mg})\end{array}$ & $\begin{array}{c}\text { Difference } \\
(\mathrm{mg})\end{array}$ \\
\hline 0.18 & $1.24_{2}$ & $1.24_{0}$ & $-0.00_{2}$ \\
0.14 & $\prime \prime$ & $1.23_{5}$ & $-0.00_{7}$ \\
0.12 & $\prime \prime$ & $1.23_{3}$ & $-0.00_{9}$ \\
0.10 & $\prime \prime$ & $1.03_{5}$ & $-0.20_{6}$ \\
0.18 & 0.124 & 0.132 & +0.008 \\
0.16 & $\prime \prime$ & 0.124 & 0.000 \\
0.14 & $\prime \prime$ & 0.128 & +0.004 \\
\hline
\end{tabular}


Table I の結果から考えて, ウランが $1 \mathrm{mg}$ 程度の ときには $0.18 \sim 0.14 \mathrm{~V}$ ，ウランが $100 \mu \mathrm{g}$ 程度になる と，0.16〜0.14 V 付近がよい結果を得るようであった。 このように試料のウラン量が少なくなったときには，最 適電位が多少低いほうへ移動する傾向があることは，前 報 ${ }^{15}$ において述べたと同じ原因によるものと思われる。 以後の実験においては，0.14Vを採用することにした。

\section{$3 \cdot 2$ ウラン $(\mathrm{VI})$ 標準溶液中のウランの定岳}

以上の研究で得た結果をもとにして, ウラン (VI) 標 準溶液中のウランを，指針 1 に示した方法によって定量 した.

Table II Determination of uranium in uranium standard solution

\begin{tabular}{|c|c|c|c|c|c|c|}
\hline \multirow{2}{*}{$\begin{array}{c}\underset{\text { taken }}{\text { Uranium }} \\
(\mu \mathrm{g})\end{array}$} & \multirow{2}{*}{$\begin{array}{l}\text { No. of } \\
\text { deter- } \\
\text { mination }\end{array}$} & \multicolumn{3}{|c|}{ Uranium found $(\mu \mathrm{g})$} & \multirow{2}{*}{$\begin{array}{c}\text { Differ- } \\
\text { ence } \\
(\mu \mathrm{g})\end{array}$} & \multirow{2}{*}{$\begin{array}{l}\text { Current } \\
\text { of } \\
\text { electrolysis } \\
(\mathrm{mA})\end{array}$} \\
\hline & & $\begin{array}{c}\text { Maxi- } \\
\text { mum }\end{array}$ & $\begin{array}{l}\text { Mini- } \\
\text { mum }\end{array}$ & Mean & & \\
\hline 621 & 2 & 627 & 617 & 622 & +1 & 2.00 \\
\hline 248 & 4 & 260 & 239 & 251 & +3 & " \\
\hline 124 & 3 & 127 & 123 & 125 & +1 & 1.00 \\
\hline 50 & 6 & 54 & 50 & 52 & +2 & 0.500 \\
\hline 25 & 6 & 29 & 25 & 26 & +1 & " \\
\hline 13 & 4 & 16 & 14 & 15 & +2 & 0.300 \\
\hline
\end{tabular}

結果は Table II に示したとおりで, $13 \mu \mathrm{g}$ までのウ ランを数 $\mu \mathrm{g}$ 程度の誤差で定量することができた．この 值は次節に述べる方法によって, $0.5 \mathrm{~g}$ の二酸化ウラン を分析したとき，0.0025\% のウラン(VI) を定量できる ことを示している.

硫酸チタンの電解液における電流密度と電流効率との 関係は, 硫酸濃度ならびにチタンイオン濃度によって大 いに変化する.これについてはすでに Lingane ら ${ }^{17) か ゙ ~}$ くわしく検討していて, 0.5 $3 \mathrm{~m} \mathrm{~A} / \mathrm{cm}^{2}$ 以下の比較的 小さい電流密度がよいとされている. 著者らは前述の白 金極を用い, Table II に示した電解電流を用いて定量 を行なったが，これはもちろん安全範囲にはいってい る.

\section{$3 \cdot 3$ 二酸化ウラン中のウラン (VI) の定量}

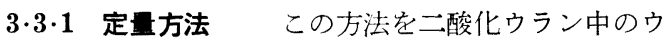
ラン (VI) の定量に応用する場合, 従来用いられてきた リン酸を用いる溶解法には多くの欠点があることは前述 した. この試料溶解法についていろいろ予備実験の結 果, 硫酸 $(2 N)$ と少量のフッ化水素酸を用いるのが適当 であることがわかったので，つぎのような指針をたて た.

\section{〔指針 2]}

試料 $0.1 \sim 0.5 \mathrm{~g}$ 分液してピペットで採取するウラン (VI) は 13〜500 $\mu \mathrm{g}\}$ を小型ケルダールフラスコ（容量 $25 \mathrm{ml}$ ) にはかりとり, 硫酸 $(2 N) 8 \sim 10 \mathrm{ml}$ およびフッ 化水素酸 $1 \sim 2$ 滴を加える. このフラスコ内に窒素ガス を通し, 約 10 分間後にしずかに煮沸する程度に加熱し て試料を完全に分解する. 試料採取量が多く, 約 20 分 間後にも分解しないときは，いったん泠却してからフッ 化水素酸 $1 \sim 2$ 滴を追加し，ふたたび加熱して試料を完 全に分解する.引続き窒素ガス気流中で泠流中で泠却し てから $25 \mathrm{ml}$ メスフラスコに移し，標線までうすめる. この溶液の一定量をピペットでとり出し, 指針 1 に示し た電位を調節した電解液に加え，以後は指針 1 にしたが って定電流電量分析を行ないウラン (VI) を定量する.

この指針中，試料溶解のときにウラン (IV) の酸化を 防ぐために窒素ガスを用いたが，これを用いない場合に も，のちに示すように結果にはほとんど影響はないもよ うであった。また，試料溶液をうすめるメスフラスコの 容積や，ピペットで採取する量などは，ウラン (VI) の 含有量に応じて適当に加減すればよい。ただし試料溶液 を電解液に加えたとき, 電解液の硫酸濃度がうすくなる おそれがあるから，この点にじゅうぶん注意しなければ ならない。なお，全実験を通じて空試験を行ない，この 值を差し引く必要があることはもちろんである。

3・3.2 定量結果 前述の方法によって, 実際に二 酸化ウランならびに八三酸化ウラン中のウラン (VI) の 定量を試みた。二酸化ウランは，ウラン (VI) 含量の少 ない試料が手にはいらなかったので，とくに微量のウラ ン（VI）を定量することができなかった．また，組成の はっきりした酸化ウラン試料として, NBS 標準試料No. 950 八三酸化ウラン（純度 $99.9 \%$ ）を分析した。

Table III Determination of $\mathrm{O} / \mathrm{U}$ ratio of uranium oxides

\begin{tabular}{|c|c|c|}
\hline \multirow{2}{*}{ Sample uranium oxides } & \multicolumn{2}{|c|}{$\mathrm{O} / \mathrm{U}$ ratio } \\
\hline & Found & Mean \\
\hline $\begin{array}{l}\mathrm{U}_{3} \mathrm{O}_{8}(\mathrm{NBS} \text { standard sample No. } 950) \\
\mathrm{O} / \mathrm{U}=2.666\end{array}$ & $\left\{\begin{array}{l}2.67_{1}, 2.65_{2} \\
2.68_{3}, 2.66_{8}\end{array}\right.$ & $2.66_{8}$ \\
\hline $\mathrm{UO}_{2}$ (Dissolved in $\mathrm{N}_{2}$ atmosphere) & $\left\{\begin{array}{l}2.108,2.115 \\
2.111,2.111 \\
2.109\end{array}\right.$ & 2.111 \\
\hline $\mathrm{UO}_{2}$ (Dissolved in air) & $\left\{\begin{array}{l}2.118,2.114 \\
2.114,2.115 \\
2.116\end{array}\right.$ & 2.115 \\
\hline
\end{tabular}

結果は Table III に示したとおりで，いずれも満足 すべき值を得た．また，二酸化ウラン試料を空気中で溶 解したときも, 窒素ガス気流中で分解したときに比べて， 
たいした差はないようであった。

(昭和 36 年 10 月，本会第 10 年会に一部発表)

$$
\text { 文献 }
$$

1) S. H. Anson, R. W. Bragdon, C. L. French, G. L. Martin : U.S.A.E.C. Rept., MDDC1435 (1947).

R. W. Stromatt, R. E. Connally : ibid., 33, 345 (1961).

2) 本島健次, 星野 昭: 原子力学会誌, 2, 1 (1960).

3) 中島史登: 本誌, 9, 961 (1960).

4) R. M. Burd, G. W. Goward : U. S. A. E. C. Rept., WAPD-205 (1959) ; Anal. Abstr., 7, 1343.

5) H. Kubota : Anal. Chem., 32, 610 (1960).

6) 武内次夫, 鈴木正巳 : 本誌, 11, 1192 (1962).

7) J. Minczewski, R. Przytycka, L. Kohman: Chem. Anal., Warsaw, 3, 27 (1958); Anal. Abstr., 7, 978.

8) L. G. Stonhill : Canad. J. Chem., 36, 1487 (1958) ; Anal. Abstr., 6, 3490.

9) G. L. Booman, W. B. Holbrook : U.S. A. E. C. Rept., IDO-14435 (1958) ; Anal. Chem., 31, 10 (1959).

10) L. G. Farrer, P. F. Thomason, M. T. Kelley: Anal. Chem., 30, 1511 (1958).

11) W. D. Shults, P. F. Thomason : ibid., 31, 492 (1959).

12) R. W. Stromatt, R. E. Connally : ibid., 33, 345 (1961).

13) J. J. Lingane, R. T. Iwamoto: Anal. Chim. Acta, 13, 465 (1955).

14) J. H. Kennedy, J. J. Lingane : ibid., 18, 240 (1958).

15）吉森孝良, 三輪智夫, 竹村天志, 伊藤 登, 武内
次夫：本誌，11，1243 (1962).

16) H. V. Malmstadt, C. B. Roberts : Anal. Chem., 27, 741 (1955).

17) J. J. Lingane, J. H. Kennedy : Anal. Chim. Acta, 15, 465 (1956).

负

Determination of uranium(VI) in $\mathrm{UO}_{2}$ by the constant current coulometry. Tsugio TAKEUCHI, Takayoshi Yoshimori** and Takashi KATo*** (* Institute of Techno-Analytical Chemistry, Faculty of Engineering, Nagoya University, Chikusa-ku, Nagoya ; ** Faculty of Engineering, Gifu University, Kagamigahara ; *** Kasamatsu Junior High School, Kasamatsu-cho, Gifu)

An accurate and simple method was described for the determination of $U(V I)$ in uranium dioxide. The method was based on the constant current coulometry using titanium sulfate electrolyte proposed by Kennedy and Lingane (Anal. Chim. Acta, 18, 240, 1958). The sample (0.1 $0.5 \mathrm{~g}$ ) was dissolved readily in a mixture of $2 \mathrm{~N}$ sulfuric acid and 1 2 drops of hydrofluoric acid, which was more preferable than the strong phosphoric acid. An aliquot of the solution was added to $35 \sim 40 \mathrm{ml}$ of the electrolyte consisting of $7 \sim$ $8 M$ sulfuric acid, $0.6 \sim 0.8 M$ titanium sulfate, 10 $\mathrm{mg}$ of ferrous ion, $50 \sim 100 \mathrm{mg}$ of uranium (IV) ion and a few drops of hydrofluoric acid. Uranium (VI) was determined coulometrically using a sensitive amperometric end point procedure.

Satisfactory results were obtained for $13 \sim 1240$ $\mu \mathrm{g}$ of uranium(VI) when the indicator circuit potential was chosen at $0.14 \sim 0.16 \mathrm{~V}$ vs. S. C. E. Results of stoichiometric analysis of uranium oxides $\left(\mathrm{UO}_{2}\right.$ and $\mathrm{U}_{3} \mathrm{O}_{8}$ ) were also tabulated.

(Received Jan. 28, 1963)

\title{
陰イオン交換樹脂法を併用したハンダ 合金中のビスマスの吸光光度定量
}

\author{
大 貫 佐一 郎*
}

ハンダ合金中の微量ビスマスを陰イオン交換分離を併用し, ヨウ化カリウムを加えて $460 \mathrm{~m} \mu$ で吸光 光度定量し，満足できる結果を得た。

ハンダ合金よりビスマスを分離するには陰イオン交換樹脂, ダイヤイオン SA \#100を用い, $8 M$ 塩 酸溶液として樹脂柱を通して鉛を除き, 财着されたスズは $2 M$ 硝酸, ビスマスは $0.5 M$ 硝酸, アンチモ ンは $1 M$ 水酸化ナトリウムで溶離した.

な抣，そのほか，ハンダ合金中に共存する銅，鉄，アルミニウム，七素，覀鉛などの微量成分は分離 できずにビスマスと共存しても，财光度測定に際して妨害するはどの量でない. 所要時間は 5 時間であ るが，ほとんど溶離扣よび蒸発濃縮に要する時間で原理的困難さはない，ハンダ合金中 $0.01 〜 0.2 \% の$ 範囲で定量可能であり，相対誤差 $3 \%$ である.鉛地金にも応用可能である.

\footnotetext{
* 東京農工大学工学部 : 東京都小金井市中町
} 